\title{
Intelligent Excitation Control System for Plant Generator
}

\author{
T. R. Rangaswamy, S. Prakash, Rathika R
}

\begin{abstract}
Excitation framework in a Power plant assumes significant job to keep up the terminal voltage of the generator at a predetermined level by controlling the exciter voltage of the generator. The most elevated level of unwavering quality requests savvy excitation framework. A tale plan for excitation control of utilizing neural controller is proposed. The current control plans experience issues to adapt up to inborn time delay, nonlinearity because of vulnerability of the excitation procedure and regular changes load. For the present work due thought has been given to $\triangle V T$ Terminal Voltage, $\omega$ Rotor Speed, $P$ Active Power and $Q$ Reactive Power. The exhibitions of proposed plans are assessed by recreation and the outcomes are contrasted and traditional controllers utilizing constant information got from the warm power plant. The upsides of the proposed plan over the current controllers are featured. [1],[3],[5]
\end{abstract}

Keywords : Excitation control, Neural network, Voltage stability, Generator.

\section{INTRODUCTION}

In a power plant the generator while delivering power additionally has likewise keep up steady terminal voltage for the electrical framework by Controlling the attractive field of the rotor which controls the voltage yield of the generator. Regularly the exciters are static. The DC control for the electromagnet is from the primary generator yield itself. Various high control thyristors correct the AC current to create a DC current which feeds to the rotor. Excitation can be constrained by differing the terminating edge of the thyristor. .During the most recent decade, broad research had been done on versatile control hypothesis, strategies and applications. M.E. Iranian et al[1], planned an Automatic voltage controller AVR for synchronous generator to keep up the terminal voltage of the generator to the evaluated worth. They likewise built up a numerical model of the synchronous generator to recreate the electrical segment of a gas power plant and do the utilitarian trial of a genuine excitation framework. The strategy was exceptionally created for transient investigation of synchronous machines given by straight differential conditions. Swasti R. KhuntiaSidharthaPanda [2], structured promotion Adaptive Neuro-Fuzzy Inference System (ANFIS) strategy dependent on the Artificial Neural Network (ANN) to a Static Synchronous Series Compensator (SSSC)- based controller for the improvement of transient soundness. The proposed ANFIS controller consolidates the upsides of a fluffy controller just as the fast reaction and flexibility nature of an ANN. The outcomes demonstrate that the proposed SSSC-based ANFIS controller is observed to be strong to blame area and changes in working conditions. Ali S. Al-Dmour [3], considered the issue of motions in a synchronous generator associated with unbounded transport through transmission lines. Two on-line control systems, to be specific, fake neural systems (ANN) and reproduced toughening (SA) are used to drop the motions in synchronous generators (SG). Reenactment consequences of applying outer unsettling influences to the synchronous generator constrained by the proposed recreated toughening controllers are contrasted with results gotten by utilizing neural system controllers. These control plans add to anticipating framework precariousness by smothering the low-recurrence motions emerging from power network flaw aggravations. Javvadi. Gowtham Sreeram et al [4], built up a framework to improve the solidness and dynamic reaction of programmed voltage guideline (AVR) framework and displayed fragmentary Order PID (FOPID) controller by utilizing Genetic Algorithm (GA) method. Correlations are made with a PID controller and demonstrated that the FOPIDcontroller can improve the exhibition of the AVR in every one of the angles. Kamal Yavarian et al,[5] displayed a half and half approach including sign to commotion proportion (SNR) and molecule swarm ptimization (PSO) for plan the ideal and keen relative essential subordinate (PID) controller of a programmed voltage controller (AVR) framework with utilizations a versatile neuro fluffy deduction framework (ANFIS). In this paper decided ideal parameters of PID controller with SNR-PSO approach for certain occasions and utilize these ideal parameters of PID controller for structure the canny PID controller for AVR framework with ANFIS. A streamlining calculation encourages this procedure and finds an ideal plan to give an ideal exhibition. Dr.G.Surya Kalyan et al [6] planned a P-I-DD controller for an Automatic Voltage Regulator (AVR) framework. The controller is planned with the end goal that it delivers a miscreant type yield reaction of the AVR framework. The plan technique is then applied to some run of the mill numerical models and time reaction reenactment of the P-I-DD controlled framework is finished. An examination of time area details like pinnacle overshoot, settling time, consistent state esteem

and so forth for reactions of AVR framework with and without P-I-DD controller is made for the models considered obviously show the

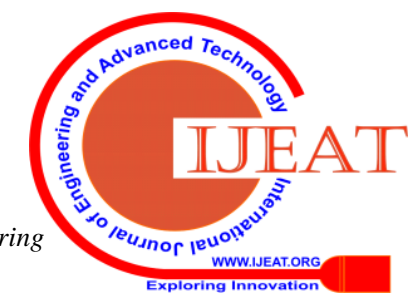


prevalence of the proposed method. [2 ],[ 4],[6]

Albeit a few strategies have been grown, a large portion of them depend on ordinary controllers. Considering the benefits of neural framework the present work manages the neural control plan applied to the excitation control of the generator in a warm power plant.

\section{EXISTING SYSTEM}

DC voltage is applied to the rotor by controlling terminating edge of the thyristors which is called controlled rectifiers. The terminating edge of Thyristors of full connect rectifier is constrained by a Regulator with the goal that required field excitation might be given. Auxiliary terminal of CT and PT associated with Generator yield terminals is nourished to controller. Based on Generator terminal voltage, the controller changes its terminating point. The schematic outline is appeared in fig1..

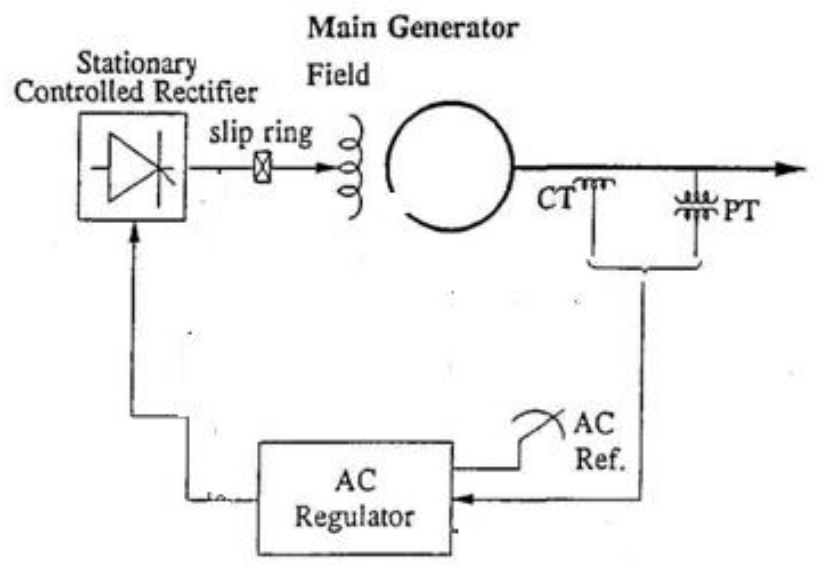

Fig.1.Conventional Exciter Control System

\section{PROPOSED INTELLIGENT SYSTEM}

The neural system engineering is made of one information layer with two neurons, two shrouded layers with seven neurons and a yield layer with one neuron. The data sources are blunder and delta mistake and the yield being the controlled variable. The information for the preparation of the neural system is acquired from the regular control. After the loads had been balanced out in the preparation procedure the loads are utilized in the genuine procedure to decide the thyrister terminating position for excitation control.

Neuro controller to controller is appeared in fig 2. The sources of info are encouraged into the information layer and get duplicated by interconnection loads as they are passed from the information layer to the main shrouded layer. Inside the primary shrouded layer, they get added then handled by a nonlinear capacity. As the handled information leaves the principal shrouded layer, again it gets duplicated by interconnection loads, at that point added and prepared constantly concealed layer. At long last the information is increased by interconnection loads at that point handled one final time inside the yield layer to create the neural system yield.. [7],[ 9],[11]
Fig.2 . Intelligent Exciter Control System

The neural system picks up utilizing a calculation got back to engendering. With back spread, the info information is over and over exhibited to the neural system. With every introduction the yield of the neural system is contrasted with the ideal yield and a blunder is processed. This blunder is then nourished back (backpropagated) to the neural system and used to alter the loads to such an extent that the mistake diminishes with every cycle and the neural model draws nearer and closer to creating the ideal yield. The lab scale test reaction is appeared in fig.3.. [8],[ 10],[12]

Comparisons of time domain specifications and the performance criteria Integral Square Error (ISE) and Integral Absolute Error (IAE) for various step changes in load are presented in Table. I.
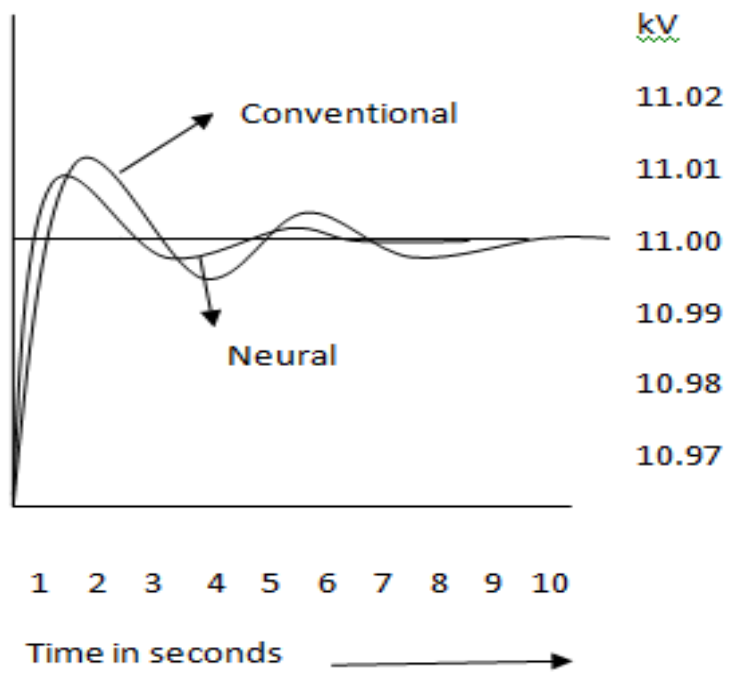

Fig:3 Vo;tage Control response

\section{TABLE I COMPARISONS OF PERFORMANCES}

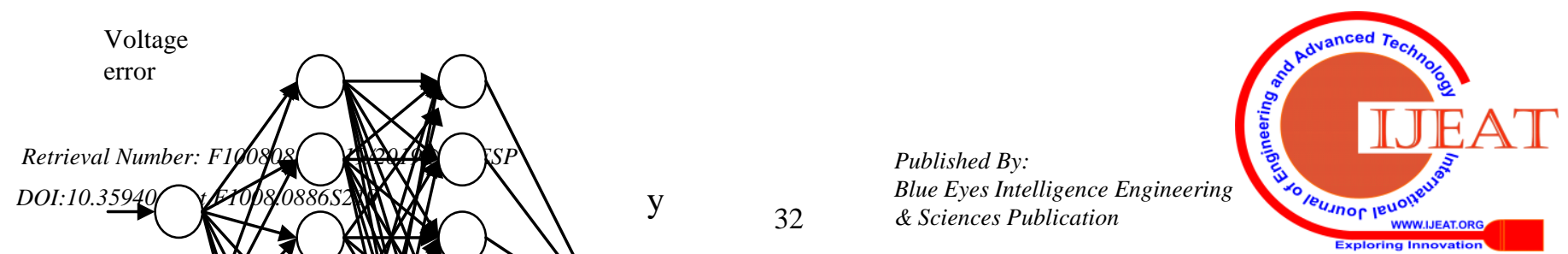




\begin{tabular}{|l|l|l|l|l|}
\hline $\begin{array}{l}\text { Control } \\
\text { scheme }\end{array}$ & \multicolumn{2}{|l|}{$\begin{array}{l}\text { Load } \\
210 \mathrm{MW}\end{array}$} & \multicolumn{2}{l|}{$\begin{array}{l}\text { Load } \\
110 \mathrm{MW}\end{array}$} \\
\hline PID & ISE & IAE & ISE & IAE \\
\cline { 2 - 5 } & 9564 & 8997 & 9655 & 8547 \\
\hline NEURO & 7988 & 7645 & 7654 & 7100 \\
\hline
\end{tabular}

\section{CONCLUSION}

The mechanical and electric failure is the maximum serious trouble faced within the wind mills. greater touchy areas like gears and turbines are extra vulnerable to faults that are the foremost reasons to have an effect on the production of wind turbine. The device fitness monitoring that is proposed here is greater crucial aspect that to mentioned. [13], [15] ,[17]

\section{REFERENCES}

[1] Sharma, R.K., Irusapparajan, G. \& Periyaazhagar, D. 2019 "Three-phase symmetric cascading Z-source seven levels multilevel inverter excited by multi carrier sinusoidal pulse width modulation scheme", International Journal of Innovative Technology and Exploring Engineering, vol. 8, no. 10, pp. 4269-4274.

[2] Velavan, R., Bharanidharan, S. \& Sheeba, B. 2019, "EMF pollution Causes, effects and protection", International Journal of Innovative Technology and Exploring Engineering, vol. 8, no. 9 Special Issue 3, pp. 1166-1168.

[3] Saravana, S., Balaji, S., Arulselvi, S. \& John Paul Praveen, A. 2019, "Reliable power quality monitoring and protection system", International Journal of Innovative Technology and Exploring Engineering, vol. 8, no. 9 Special Issue 3, pp. 644-645.

[4] Tamil Selvan, S. \& Sundararajan, M. 2019, "Performance Parameters of 3 Value $8 \mathrm{t}$ Cntfet Based Sram Cell Design Using H-Spice", International Journal of Recent Technology and Engineering, vol. 8, no. 2 Special issue 5, pp. 22-27.

[5] Jac Fredo, A.R., Abilash, R.S., Femi, R., Mythili, A. \& Kumar, C.S. 2019, "Classification of damages in composite images using Zernike moments and support vector machines", Composites Part B: Engineering, vol. 168, pp. 77-86.

[6] Kathiravan, P. \& Govindaraju, C. 2019, "Design and evaluation of ultra gain isolated DC-DC converter for photovoltaic system", International Journal of Engineering and Advanced Technology, vol. 8, no. 5, pp. 2646-2651.

[7] Kripa, N., Vasuki, R. \& Kishore Kanna, R. 2019, "Realtime neural interface controlled au-pair BIMA bot", International Journal of Recent Technology and Engineering, vol. 8, no. 1, pp. 992-994.

[8] Mohanraj, Meenaa Kumari, M., Philomina, S. \& Jasmin, M. 2019, "In-situ humidity measurement of hydrogen fuel cell car using MEMS sensor", International Journal of Recent Technology and Engineering, vol. 8, no. 1, pp. 41-43.

[9] Velmurugan, T. \& Prakash, S. 2019, "Artificial intelligent based distribution automation of swift fault detection isolation and power restoration for HT network", International Journal of Innovative Technology and Exploring Engineering, vol. 8, no. 6, pp. 1-6.

[10] Dwarakesh, K. \& Prem Kumar, G. 2019, "Five-level inverter based sequential boost system using fuzzy logic controller", International Journal of Innovative Technology and Exploring Engineering, vol. 8, no. 6, pp. 12-19.

[11] Anne Gifta, A. \& Hemavathi, G. 2019, "Analysis of grid tied solar PV system using ANFIS Algorithm", International Journal of Innovative Technology and Exploring Engineering, vol. 8, no. 6, pp. 312-316.

[12] Jayavel, R., Rangaswamy, T.R. \& Prakash, S. 2019, "Efficient grid management system with renewable and conventional power sources", International Journal of Innovative Technology and Exploring Engineering, vol. 8, no. 6, pp. 287-289.

[13] Hemavathi, G. \& Maheshwaran, S. 2019, "Proportional resonant controlled high gain step-up converter system with improved response",
International Journal of Innovative Technology and Exploring Engineering, vol. 8, no. 6, pp. 317-323.

[14] Periyaazhagar, D. \& Irusapparajan, G. 2019, "Design and completion of asymmetric single phase 27 level cascaded mli for various pwm scheme", International Journal of Innovative Technology and Exploring Engineering, vol. 8, no. 6, pp. 792-797.

[15] Mahalakshmi, V. \& Vijayaragavan, S.P. 2019, "PV based power electronic converters for high voltage DC applications", International Journal of Recent Technology and Engineering, vol. 7, no. 6, pp. 670-674.

[16] Irusapparajan, G., Periyaazhagar, D., Prabaharan, N. \& Rini Ann Jerin, A. 2019, "Experimental verification of trinary DC source cascaded h-bridge multilevel inverter using unipolar pulse width modulation", Automatika, vol. 60, no. 1, pp. 19-27.

[17] Sangeetha, G., Sherine, S., Arputharaju, K. \& Prakash, S. 2019, "On Line Monitoring of Higher Rated Alternator using Automated Generator Capability Curve Administer", Proceedings of the IEEE International Conference on \&amp;quot;Recent Trends in Electrical, Control and Communication\&amp;quot;, RTECC 2018, pp. 176

[18] Bycil, V.J. \& Wiselin, M.C.J. 2019, "Modeling and analysis of vibration energy harvesting system using piezo stack", International Journal of Mechanical and Production Engineering Research and Development, vol. 9, no. Special Issue 1, pp. 523-533.

[19] Sripada, A., Warrier, A., Kapoor, A., Gaur, H. \& Hemalatha, B. 2018 , "Dynamic lateral balance of humanoid robots on unstable surfaces", International Conference on Electrical, Electronics, Communication Computer Technologies and Optimization Techniques, ICEECCOT 2017, pp. 539.

[20] Srinivasan, S., Thirumalaivasan, K. \& Sivakumaran, T.S. 2018 , "Performance evaluation of double-output luo converters", Journal of Advanced Research in Dynamical and Control Systems, vol. 10, no. 10 Special Issue, pp. 870-878.

[21] Karthikayen, A. \& Selvakumar Raja, S. 2018, "A skellam distribution inspired trust factor-based selfish node detection technique in MANETs", Journal of Advanced Research in Dynamical and Control Systems, vol. 10, no. 13, pp. 940-949.

\section{AUTHORS PROFILE}

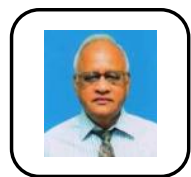

Dr.T.R.Rangaswamy, Professor Department of EEE,Bharath Institute of Higher education and research, Tamilnadu, India

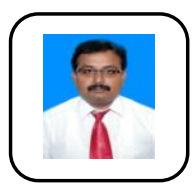

Dr.S.Prakash, Professor Department of EEE, Bharath Institute of Higher education and research, Tamilnadu, India

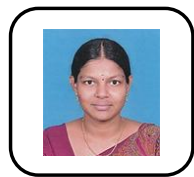

Rathika R, Assistant Professor Department of EEE, Bharath Institute of Higher education and research, Tamilnadu, India. 